\title{
Introducing Literature in the Discourse of Artistic Research
}

\author{
Corina Caduff and Tan Wälchli
}

The discourse of artistic research emerged in anglophone and Scandinavian countries in the 1990s, initially being established in the Visual Arts departments of art schools. In the wake of the Bologna Process, it spread to many other countries and reached the fields of design, theatre, film, music, and dance. The unification of so many different artistic disciplines under the roof of one discourse represents a great achievement. After long debates about procedures, methods and outcomes of artistic research, and after terminological discussions about embodied and tacit knowledge as well as research into art, for art, and through art, the field is well-established, both theoretically ${ }^{1}$ and institutionally. ${ }^{2}$ It provides rich ground for countless individual works and methodologies, employing a variety of epistemological models as well as transdisciplinary, collaborative, and participatory practices. ${ }^{3}$

1 See Christopher Frayling, Research in Art and Design. Royal College of Art Research Papers 1:1. London: Royal College of Art, 1993; Annette Balkema/Henk Slager, Artistic Research. Amsterdam: Rodopi, 2004; Mika Hannula et al., Artistic Research: Theories, Methods and Practices. Helsinki: Academy of Fine Arts, 2005; Robin Nelson, "Practice-as-Research and the Problem of Knowledge," in: Performance Research 11: 4 (2006), pp. 105-116; Dieter Lesage/Kathrin Busch, eds., A Portrait of the Artist as a Researcher. The Academy and the Bologna Process. Antwerp: MuHKA, 2007; Tom Holert, "Being Concerned? Scattered Thoughts on 'Artistic Research' and 'Social Responsibility', in: Florian Dombois et al., eds., Intellectual Birdhouse. Artistic Practice as Research. London: Koenig Books, 2012, pp. 23-39; Henk Borgdorff, The Conflict of the Faculties. Perspectives on Artistic Research and Academia. Leiden: Leiden University Press, 2012; Janneke Wesseling, Of Sponge, Stone and the Intertwinement with the Here and Now. Methodology of Artistic Research. Amsterdam: Valiz, 2016.

2 James Elkins, Artists with PhDs. On the New Doctoral Degree in Studio Art. Washington, DC: New Academia Publishing, 2009 gives an overview on $\mathrm{PhD}$ programmes in visual arts around the world and discusses some methodological discrepancies. An overview of institutional achievements in the German language area is provided by Sandra Buck et al., "Künstlerische Forschung unter Bildungsperspektive: individualisierte Studienprogramme?", in: Zeitschrift für Hochschulentwicklung 10:1 (2015), pp. 52-73, http://www.zfhe.at/index.php/zfhe/article/ view/802, date of access: 17 Sept. 2018.

3 The online Journal for Artistic Research, established in 2011, provides insight into the scope of contemporary practices in the field. Cf. http://www.jar-online.net, date of access: 17 Sept. 2018. For a broad view on various methodological approaches, cf. Jens Badura et al., eds., Künstlerische Forschung. Ein Handbuch: Zurich: diaphanes 2015. For some recent participatory tendencies, cf. Corina Caduff, "Artistic Research: Methods - Development of a 
Considering the international success story of artistic research throughout the various artistic disciplines, it appears somewhat striking that the discipline of literature has so far not participated in the discourse. The reasons for this seem to be primarily of an institutional nature. While creative writing programmes are available as a type of professional literary training analogous to studies in photography, film, painting, music, theatre, etc., such programmes are usually embedded within the humanities; in the United States of America and Great Britain, traditionally within English departments. ${ }^{4}$ Only in exceptional cases - and during the last decade - have creative writing programmes been established at art academies, art universities, and art schools. ${ }^{5}$ Therefore, creative writing programmes are seldom related to other forms of arts education. And this explains why discussions about artistic research, still generally taking place at art schools, rarely include literature.

\section{Writers and Scholars In-Between}

Although literature as a discipline is not represented in the artistic research discourse, numerous individual writers and scholars have ties to a variety of institutional constellations in which overlaps between literature, art, and research become manifest:

- Writers who teach their literary practice in new institutional contexts. In addition to the new creative writing programmes at art schools, a few recently set up programmes also foster specifically conceptual and transdisciplinary modes of 'art writing' at universities.

- Writers who are increasingly employed by art schools to teach thesis writing classes. As a result of the establishment of artistic research and especially in view of $\mathrm{PhD}$ programmes, thesis writing is gaining importance already at MA level.

- Transdisciplinary writers who are active in several fields of the arts, and who are also teaching their particular crossover practices to younger colleagues.

Discourse - Current Risks," in: Kirsten Merete Langkilde, ed., Poetry of the Real. Basel: FHNW 2017, pp. 311-323.

4 On the rise of creative writing programmes in anglophone countries, cf. Paul Dawson, Creative Writing and the New Humanities. London, New York, NY: Routledge, 2004; Mark McGurl, The Program Era. Postwar Fiction and the Rise of Creative Writing. Cambridge, MA: Harvard University Press, 2011.

5 Such as the BA in Literary Writing at the University of the Arts, Bern (since 2006); the BA Language Arts at the University of Applied Arts, Vienna (since 2009/2010); and the MFA Literary Composition at the Valand Academy, University of Gothenburg (since 2014). 
- Literary scholars who teach creative writing or 'theory' classes at art schools.

- Art historians and cultural historians who inquire and observe the emergence and development of artistic research as a discipline.

This volume comprises the work of 16 such writers and scholars who are institutionally located in nine Western European countries. They expand on their methodological approaches as well as their practice, and they analyse exemplary case studies. Presenting their points of view next to one another might allow the delineation — albeit provisionally — of the meandering boundaries of a future field of practice-based 'literary research.' This will quite likely not be a homogenous field, but one constituted by a variety of activities and institutional allocations. Nevertheless, the different areas are interconnected and do participate in a common discourse. In this sense, the volume aims to compile an inventory of prevalent observations, overarching questions, and shared challenges. A number of these concern the status, form, and function of a written thesis in practice-based research. Others derive from debates about various kinds of knowledge that such research might bring about.

\section{Literary Self-Reflection}

As mentioned before, the current exclusion of literature from debates on artistic research is primarily due to the embedding of creative writing programmes in the humanities, in the field of monolingual cultural and literary studies. Nevertheless, some of these programs inevitably raise questions about the conditions and requirements for practice-based research in literature, since they offer 'third circle' studies leading to a $\mathrm{PhD}$ degree. The starting point for this debate is the stipulation, common in the other arts, that an accompanying, explanatory or reflective text should be added to the artistic research workeven though the proportion of such additional texts varies greatly between different countries and curricula. ${ }^{6}$ As a consequence, there is a tendency in the

6 Early debates on artistic research revealed considerable disagreement over the necessity and role of an explanatory text. For opposing positions, cf., for example, Christoph Schenker, "Kunst als Forschung," in: Peter Emch et al., eds., Kunstklasse: Studiengang Bildende Kunst, Hochschule für Gestaltung und Kunst Zürich: Inserts, Texte, Statements, Zurich: Hochschule für Gestaltung und Kunst, 1998, pp. 21-29: here p. 28; and Hannula et al. (2005), Artistic Research, p. 165. In December 2016, the ELIA 'Florence Principles in the Arts' were published: http://www.elia-artschools.org/userfiles/File/customfiles/1-the-florence-principl es20161124105336_20161202112511.pdf. According to these principles, a "discursive component" alongside the artwork is required: "The project consists of original work(s) of art and contains a discursive component that critically reflects upon the project and documents the research 
field of creative writing to demand two texts for an artistic PhD: in addition to the literary work, a supplementary, explanatory text in which the writer methodologically reflects and contextualises their working and writing.

In the history of literature, such explanatory treatises have long formed the genre of poetology. It includes reflections on literature and language by writers, who-often in pieces that supplement their creative texts—-deal with the philosophical premises, historical reference points and linguistic procedures of their work. It is the detachment from the actual artwork or the autonomisation of the poetological component respectively which institutionally constitutes artistic research today, and which, of course, leads to further questions: Can such a detachment be both mandatory and theoretically justified in the field of creative writing, or is it rather an obstructive antinomy (Jan Baetens, University of Leuven)? And how precisely can an institutional requirement become productive in the context of creative writing $\mathrm{PhD}$ programmes at art schools (Fredrik Nyberg, Valand Academy, Gothenburg)? In other research contexts at art schools, too, writers find themselves motivated to explore the possibilities of separate, poetological text experiments (Maya Rasker, University of the Arts, Utrecht).

\section{Writing in Art and Artistic Research}

Because artistic research in general often requires a supplementary text component for reflection and contextualisation, artists from all disciplines increasingly see themselves obliged to write. In a variety of practices, they employ language as a medium of reflection, as a mediator of the artwork, as a component of transdisciplinary practices, etc. However, such 'artistic' practices of writing are not an entirely new phenomenon. Through the avant-garde movements and since, language has, in the course of the 2oth century, been integrated into other artistic forms in diverse ways. While at first serving as an artistic medium of expression alongside others, for example in text and image collages or in the formulation of artistic programmes and manifestos, in the second half of the 2oth century the writing of texts in the context of conceptual art advanced to become a valid artistic mode of its own.

In hindsight, this historical development can be viewed as a prerequisite for the emergence of artistic research. Particularly in the aftermath of Marcel Duchamp's and the various permutations of conceptual art, artists were

process." (p. 7), date of access: 17 Sept. 2018 [emphasis added by us]. The term "discursive" eventually leaves it open to being an oral or written component. 
able to enter universities and starting to undertake 'research,' which sometimes granted them a degree of financial security they hadn't previously had access to (Christa-Maria Lerm Hayes, University of Amsterdam). Meanwhile, the inclusion of texts in the artistic practice of feminist artists of the 1960s and 70 served to assert a new, by then female-attributed skill, and brought about early forms of documentary-researching procedures (Redell Olsen, Royal Holloway, University of London). In all cases, the new artistic text productions expaned the established literary genres - such as prose, drama, and poetry - and they brought about productive interactions between the disciplines. Recently, an even stronger and more diverse proliferation of conceptual writing has been developing across all artistic disciplines (Maria Fusco, Northumbria University). In the narrower area of the politically and institutionally defined artistic research, meanwhile, the question has arisen as to which forms and procedures are suitable for a complementary, reflective text. Should artists who write a PhD or an MFA thesis adhere to the standards of, for example, academic, theoretical, or critical texts? Or shouldn't they rather develop their own, idiosyncratic writing methods in order to textually express the specifics of their respective work (Daniela Cascella, University of the Arts, London)? A revealing example of this is the challenge of making the speechlessness of a visual work perceptible without subjecting it to an analytical language of interpretation (Salomé Voegelin, University of the Arts, London).

\section{The Knowledge of Literature}

Current reflections on the production of knowledge in practice-based art research follow the debates about tacit and embodied knowledge, as mentioned earlier, and they explore epistemological considerations regarding the peculiar kinds of knowledge accessible to the arts - in contrast to the sciences, for example. ${ }^{7}$ Such discussions may also be instructive for literary research since one can equally ask what kinds of knowledge are produced and passed on in a work of literature. For example, in the last fifteen years the knowledge gained from literary metaphors, procedures, or narratives has been examined from a

7 The discussions on "Artistic Knowledge, Part 1" and "Artistic Knowledge, Part 2" in: James Elkins, ed., What Do Artists Know? University Park, PA: University of Pennsylvania Press, 2012, pp. 39-45 and pp. 47-57, provide examples for the ongoing debates about epistemological categories and various kinds of tacit knowledge, respectively. From a philosophical vantage point, Dieter Mersch, Epistemologies of Aesthetics, translated by Laura Radosh. Zurich: diaphanes, 2015 [2015] develops criteria for distinguishing artistic forms of knowledge from scientific ones. 
scholarly perspective, and literary references to other disciplines of knowledge have been revealed. ${ }^{8}$ Along these lines, practice-based literary research, too, might examine the knowledge contained in various forms of speech and writing, or it might experiment with including material from archives, encyclopaedias, and scientific research in the fictional text. In any case, in the interest of artistic research, it is important to ensure that the research questions are recognisable and comprehensible and that a knowledge gain is clearly identifiable.

In various contemporary writing practices the examination of linguistic phenomena from everyday language is pursued as a fruitful strategy for the production of new knowledge. For example, political and military language rules can be analysed in terms of their functions and modes of action by making use of literary and documentary methods (Vincent Broqua, University Paris 8). When everyday language rules exert formative societal influence, their literary examination may lead to a critical analysis of social norms (Ferdinand Schmatz, University of Applied Arts, Vienna). And as the linguistic representation of the world is hardly to be separated from seeing and knowing the world, new linguistic procedures often create new views of the world (Alexander Damianisch, University of Applied Arts, Vienna). In a Wittgensteinian perspective, finally, literary research might explore different 'aspects' of everyday words, metaphors or linguistic imagery, thereby highlighting various functions of language that remain unexplored in everyday use (Tine Melzer, Bern University of the Arts).

\section{Models and Precursors}

While the essays in the previous chapter present contemporary conceptions of literary knowledge production, the question can also be approached from the rather scholarly vantage point of cultural history. Historical instances of literary knowledge production that were consciously and strategically developed as artistic experiments-sometimes in exchange or in coincidence with innovations in the humanities or the natural sciences-might be instructive for understanding certain strategies of 'artistic research' avant la lettre. Again, such methodological considerations of identifying historical precursors or models are also common in the more general discourse on

8 Cf. Sigrid Weigel/Bernhard Dotzler, eds., "fülle der combination“. Literaturforschung und Wissenschaftsgeschichte. München: Wilhelm Fink, 2005; Michael Wood, Literature and the Taste of Knowledge. Cambridge: Cambridge University Press, 2005; John Gibson, "Literature and Knowledge," in: Richard Eldridge, ed., The Oxford Handbook of Philosophy and Literature. Oxford: Oxford University Press, 2009, pp. 467-485; Roland Borgards et al., eds., Literatur und Wissen. Ein interdisziplinäres Handbuch. Stuttgart: J. B. Metzler, 2013. 
artistic research, ${ }^{9}$ and again they can be re-considered for the field of literature. Without providing an overview or a representative selection, the last four contributions to this volume examine exemplary cases from the second half of the 2oth century.

Chris Kraus's novel I Love Dick (1997)—blending autobiography, French Theory and art criticism with performative and experimental elements as well as older forms such as the epistolary novel and the diary-has become an influential role model for contemporary transdisciplinary forms of writing. In her own kind of 'research' practice, Kraus thoroughly re-considered the form of the novel as well as the precarious position of the female intellectual at the end of the 2oth century (Anneleen Masschelein, University of Leuven). At around the same time, Oskar Pastior worked on his 'organised' translations of Charles Baudelaire. Exploring various ways of staying true to the sounds and rhythms of poems, while mostly ignoring semantics, he examined the conflicted relations between original and translation, speech and writing, French and German (Thomas Strässle, University of the Arts, Bern). In the late 197os, Roland Barthes developed new writerly forms situated in between essay and novel, critique and narration, which resulted from and reiterated some of his scientific findings about the role of the author, various kinds of artistic languages, semiology, etc. (Kathrin Busch, Berlin University of the Arts). Another twenty years earlier, Vienna poet Konrad Bayer combined linguistic methodologies of his time with inquiries into the lasting imprint of National Socialism in German language (Tan Wälchli, Zurich University of the Arts). Taken together, these scattered examples indicate that literary 'research' strategies avant la lettre resulted from very different incentives - biographical, cultural, political, etc.-and aimed to produce new knowledge about various aspects of language and literary forms as well as their historical contexts and conditions.

\section{Multi- and Monolingualism}

Not least the examples from the final chapter might also serve as reminders that literary practices are inextricably bound to national languages: English, French, German, etc. This equally applies to contemporary creative writing

9 A prime example from the visual arts are the painterly innovations by Paul Cézanne. Since Merlau-Ponty's influential treatises-Le doute de Cézanne (1945) and, in particular, L'oeuil et l'ésprit (1960)—Cézanne's new ways of painting have often been regarded as coinciding or competing with innovations in the scientific understanding of vision and perception, and therefore as an example of artistic research avant la lettre (cf., for example, Michael Cobussen, "The Intruder," in: Corina Caduff et al., eds., Art and Artistic Research. Zurich: Scheidegger \& Spiess, 2010, pp. 46-54: here pp. 48-49). 
training including related methodological discussions. Since each language produces its own specific poetic aspects, their discussion and treatment require the same language and are not easily transferable to any other. For this reason alone, an international discourse on 'literary research' will hardly ever be homogeneous. While the international debate about artistic research in genral, which can be considered as a metadiscourse, is usually conducted in English, any future field of practice-based literary research will always be characterised by differences grounded in multilingualism that demand recognition.

\section{Bibliography}

Badura, Jens et al., eds., Künstlerische Forschung. Ein Handbuch. Zurich: diaphanes, 2015 .

Balkema, Annette/Henk Slager, Artistic Research. Amsterdam: Rodopi, 2004.

Borgards, Roland et al., eds., Literatur und Wissen. Ein interdisziplinäres Handbuch. Stuttgart: J. B. Metzler, 2013.

Borgdorff, Henk, The Conflict of the Faculties. Perspectives on Artistic Research and Academia. Leiden: Leiden University Press, 2012.

Buck, Sandra et al., "Künstlerische Forschung unter Bildungsperspektive: individualisierte Studienprogramme?", in: Zeitschrift für Hochschulentwicklung 10:1 (2015), pp. $5^{2-73}$, http://www.zfhe.at/index.php/zfhe/article/view/802, date of access: 17 Sept. 2018.

Caduff, Corina, "Artistic Research: Methods - Development of a Discourse - Current Risks," in: Kirsten Merete Langkilde, ed., Poetry of the Real. Basel: FHNW, 2017, pp. 311-323.

Cobussen, Michael, "The Intruder," in: Corina Caduff et al., eds., Art and Artistic Research. Zurich: Scheidegger \& Spiess, 2010, pp. 46-54.

Dawson, Paul, Creative Writing and the New Humanities. London, New York, NY: Routledge, 2004.

Elkins, James, Artists with PhDs. On the New Doctoral Degree in Studio Art. Washington, DC: New Academia Publishing, 2009.

Elkins, James, ed., What Do Artists Know? University Park, PA: University of Pennsylvania Press, 2012.

Frayling, Christopher, Research in Art and Design. Royal College of Art Research Papers 1:1. London: Royal College of Art, 1993.

Gibson, John, "Literature and Knowledge," in: Richard Eldridge, ed., The Oxford Handbook of Philosophy and Literature. Oxford: Oxford University Press, 2009, pp. 467-485. 
Hannula, Mika et al., Artistic Research: Theories, Methods and Practices. Helsinki: Academy of Fine Arts, 2005.

Holert, Tom, "Being Concerned? Scattered Thoughts on 'Artistic Research' and 'Social Responsibility'," in: Florian Dombois et al., eds., Intellectual Birdhouse. Artistic Practice as Research. London: Koenig Books, 2012, pp. 23-39.

Lesage, Dieter/Kathrin Busch, eds., A Portrait of the Artist as a Researcher. The Academy and the Bologna Process. Antwerp: MuHKA, 2007.

McGurl, Mark, The Program Era. Postwar Fiction and the Rise of Creative Writing. Cambridge, MA: Harvard University Press, 2011.

Mersch, Dieter, Epistemologies of Aesthetics, translated by Laura Radosh. Zurich: diaphanes, 2015 [2015].

Nelson, Robin, "Practice-as-Research and the Problem of Knowledge," in: Performance Research 11:4 (2006), pp. 105-116.

Schenker, Christoph, "Kunst als Forschung," in: Peter Emch et al., eds., Kunstklasse: Studiengang Bildende Kunst, Hochschule für Gestaltung und Kunst Zürich: Inserts, Texte, Statements. Zurich: Hochschule für Gestaltung und Kunst, 1998, pp. 21-29.

Weigel, Sigrid/Bernhard Dotzler, eds., "fülle der combination“. Literaturforschung und Wissenschaftsgeschichte. München: Wilhelm Fink, 2005.

Wesseling, Janneke, Of Sponge, Stone and the Intertwinement with the Here and Now. Methodology of Artistic Research. Amsterdam: Valiz, 2016.

Wood, Michael, Literature and the Taste of Knowledge. Cambridge: Cambridge University Press, 2005. 